Fiat Iustitia : Jurnal Hukum

Volume 2 No. 1 Maret 2021

\title{
PERTANGGUNGJAWABAN PIDANA TERHADAP PENGGUNAAN ALAT TANGKAP IKAN ILLEGAL
}

\author{
Ica Karina \\ Fakultas Hukum Universitas Katolik Santo Thomas, Medan, Indonesia \\ Email: ichakarina14@gmail.com
}

\begin{abstract}
ABSTRAK
Penangkapan ikan secara illegal merupakan tindak pidana khusus karena diatur dengan undang-undang tersendiri, yaitu Undang-undang No. 31 Tahun 2004. Illegal fishing adalah kegiatan penangkapan ikan yang bertentangan dengan perundang-undangan suatu negara atau ketentuan internasional. Penangkapan ikan secara illegal yakni penangkapan ikan dengan menggusakan alat/bahan penangkapan ikan yang berbahaya, dan tanpa diserta izin yang lengkap serta melanggar daerah atau jalur atau waktu penangkapan ikan yang ditetapkan.

Adapun tujuan penelitian ini adalah Untuk mengetahui pengaturan hukum terhadap tindak pidana penggunaan alat tangkap ikan illegal.Untuk mengetahui bentuk sanksi pidana/hukuman terhadap penggunaan alat tangkap ikan. Teknik pengumpulan data yang digunakan dalam penelitian ini adalah melalui studi kepustakaan untuk mendapatkan konsepsi, teori atau doktrin, pendapat atau pemikiran konseptual dari peneliti pendahulu yang berhubungan dengan objek penelitian ini yang dapat berupa peraturan perundang-undangan maupun sumber lainnya. Penelitian ini bersifat deskriptif analitis, jenis penelitian yang akan dilakukan dalam penelitian ini adalah penelitian yuridis normatif

Hasil penelitian menunjukkan bahwa terhadap pelaku tindak pidana di bidang perikanan pada prinsipnya hanya dapat dilakukan apabila diketahui terdapat cukup bukti telah terjadi tindak pidana di wilayah Zona Ekonomi Eksklusif Indonesia sebagaimana diatur dalam Undang-Undang Nomor 45 Tahun 2009 tentang Perikanan yang dilakukan oleh setiap orang atau badan hukum.
\end{abstract}

Kata Kunci : Pertanggungjawaban pidana, Alat Tangkap Ikan, Illegal

\begin{abstract}
Illegal fishing is a special crime because it is regulated by a separate law, namely Law No. 31 of 2004. Illegal fishing is fishing activity that is against the laws of a country or international provisions. Illegal fishing is fishing by destroying dangerous fishing tools / materials, without complete permits and violating the stipulated fishing area or route or time.

The purpose of this research is to find out the legal arrangements for the criminal act of using illegal fishing gear. To find out the form of criminal sanctions / penalties for the use of fishing gear. The data collection technique used in this research is through literature study to obtain conceptions, theories or doctrines, opinions or conceptual thoughts from predecessor researchers related to the object of this research, which can be in the form of legislation or other sources. This research is descriptive analytical, the type of research to be carried out in this research is normative juridical research

The results show that perpetrators of criminal acts in the field of fisheries in principle can only be carried out if it is known that there is sufficient evidence that a criminal act
\end{abstract}


has occurred in the Indonesian Exclusive Economic Zone as regulated in Law Number 45 of 2009 concerning Fisheries by any person or body. law.

Keywords: criminal responsibility, fishing gear, illegal

\section{A. PENDAhuluan}

Indonesia merupakan Negara yang memiliki bentang garis pantai dengan panjang $81.000 \mathrm{KM}$, sehingga menjadikan laut Indonesia dan wilayah pesisir Indonesia memiliki kandungan kekayaan dan sumber daya alam hayati yang sangat berlimpah ikannya, terumbu karang, hutan mangrove dan lain sebagainya. ${ }^{1}$ Menurut UndangUndang Nomor 45 Tahun 2009 tentang perubahanatas Undang-Undang No.31 Tahun 2004 tentang Perikanan, perikanan adalah semua kegiatan yang berhubungan dengan pengelolaan dan pemanfaatan sumberdaya ikan dan lingkungannya mulai dari praproduksi, produksi, pengelolaan sampai dengan pemasaran yang dilaksanakan dalam suatu sistem bisnis perikanan. Tindak pidana perikanan ini paling sering terjadi di wilayah pengelolaan perikanan Indonesia adalah pencurian ikan oleh kapal-kapal asing yang berasal dari beberapa Negara seperti negara Thailand, Fillipina dan Vietnam, walaupun sulit untuk memetakan dan mengestimasi tindak pidana perikananyang terjadi di wilayah perairan Indonesia. ${ }^{2}$ Perikanan mempunyai peran penting dan strategis dalam pembangunan perekonomian nasional, terutama dalam meningkatkan perluasan kesempatan kerja, pemerataan pendapatan dan meningkatkan taraf hidup bangsa pada umumnya, nelayan kecil pembudidaya ikan kecil dan pihak-pihak pelaku usaha di bidang perikanan.

\footnotetext{
1 Supriadi dan Alimudin, 2001, Hukum Perikanan Di Indonesia, Sinar Grafika, Jakarta, hlm. 2.

2 Ibid.
}

Hal ini dilakukan dengan tetap memelihara lingkungan, kelestarian dan ketersediaan sumber daya ikan.Sumber daya ikan adalah semua jenis ikan yang di difinisikan sebagai segala jenis organisme yang seluruh atau sebagian dari siklus hidupnya berada di dalam lingkungan perairan. Dalam kegiatan perikanan cara penangkapan ikan dan alat yang dipergunakan berkembang sangat cepat dengan tujuan untuk memperoleh ikan dalam waktu yang relatif singkat dan dalam jumlah yang besar. Dalam kamus istilah perikanan, penangkapan adalah usaha melakukan penangkapan atau pengumpulan ikan dan jenis-jenis sumber hayati lainnya dengan dasar bahwa ikan dan sumber hayati tersebut mempunyai manfaat atau mempunyai nilai ekonomis. ${ }^{3}$ Secara geografis, ekonomi maupun sosial memiliki keterkaitan yang sangat erat antaratanah dengan orang-orang yang berdiam di darat, serta dibenarkan dengan memberikan prioritas bagi penduduk atau warga yang menempati wilayah tersebut dengan tujuan untuk memanfaatkan kekayaan dan sumber daya alam laut yang dekat dengan wilayah pantainya. Keadaan yang dialami oleh masyarakat Indonesiaberanggapan bahwa wilayah daratan dan laut yang berada disekitarnya serta mengelilingi pulaupulau di Indonesia merupakan suatu bagian dari kehidupan bangsa Indonesia. ${ }^{4}$

Para pelaku pelaggaran Illegal Fishing di perairan ZEEI bagi kapal

\footnotetext{
Eddy Afrianto, 1996, Kamus Istilah Perikanan, Kanisius, Bandung, hlm 10.

4 Frans E. Likadja, 1998, Bungan Rumpai Hukum Laut Internasional, Bina Cipta, Bandung, hlm. 58
} 
asing dikenakan sanksi denda yang lebih besar dan pantas sehingga tidak menimbulkan kerugian besar bagi negara pantai, serta akan memberikan efek jera bagi pelaku pelanggaran illegal Fishing terhadap kapal asing. Sedangkan pelanggaran Illegal Fishing oleh negara pantai dikenakan sanksi hukuman yang berlaku di Negara tersebut. $^{5}$ Negara pantai hanya dapat melaksanakan pengelolaan dan pemanfaatan sumber daya hayati diwilayah perairan eksklusif Indonesia dan hanya dapat melakukan proses penahanan sampai ketingkat pengadilan sesuai perjanjian hukum laut Internasional dan tidak diperboleh melaksanakan hukum penjara, asalkan ada kerjasama dan kesepakatan antar Negara tersebut. Serta segera menginformasikan sanksi yang diberikan para pelaku pelanggaran illegal Fishingkepada Negara yang melakukan tindak pidana. ${ }^{6}$ Dalam pelanggaran tindak pidana perikanan oleh kapal asing ZEEI, yang telah ditahan oleh Negara pantai secepat mungkin dibebaskan dengan ganti rugi yang pantas yang diterima oleh Negara pantai.Penahanan tidak diizinkan dalam bentuk kurungan penjara.Untuk mendukung penegakan hukum tindak pidana illegal Fishing yang terjadi di Negara Indonesia telah ditetapkan beberapa Undang-Undang dan peraturan pemerintah ${ }^{7}$, sehingga payung hukum yang digunakan menjadi semakin kuat. Sebagai Negara kepulauan terbesar di dunia, dimana sebagai besar wilayahnya terdiri dari laut, Indonesia merupakan salah satu

5 Chairul Anwar, 1998, Horizon Baru Hukum Laut Internasional, Rhineka Cipta, Jakarta, hlm. 36

6 E Mantjoro dan Potoh O, 1993, Internasional Fishier Policy (Kebijaksanaan Perikanan Internasional), Alumni, Bandung, hlm. 73.

7 Ibid.
Negara yang memiliki Sumber Kekayaan Alam Laut (SKAL) yang menjanjikan untuk di eksplorasi dan dieksploitasi sebagai penggerak utama pembangunan nasional.Namun selama tiga dasawarsa pembangunan nasional, potensi dibidang kelautan (ekonomikelautan) masih diposisikan sebagai sektor pinggiran serta tidak menjadi arus utama dalam kebijakan pembangunan nasional. ${ }^{8}$ Penangkapan ikan secara illegal atau yang disebut pencurian ikan (illegal Fishing) sangat merugikan Negara maupun nelayan tradisional.Nelayan tradisional merupakan masyarakat Indonesia, sehingga masyarakat pesisir tersebut juga terkena imbas dari pencurian ikan ini. Selain itu masyarakat lain yang menjadi konsumen juga ikut dirugikan karena tidak biasa menikmati hasil laut di Negeri sendiri. Secara makro, ikanikan Indonesia diolah dengan peralatan baik sehingga meningkatkan harga jualnya diluar negeri. ${ }^{9}$

Pengelolaan perikanan merupakan upaya yang sangat penting dalam mengantisipasinya terjadinya kompleksitas permasalahan baik ekonomi maupun sosial ekonomi di wilayah pesisir dan laut.Upaya ini muncul sebagai akibat dari pemanfaatan kawasan pesisir dan laut yang open access.Praktek open access yang selama ini banyak menimbulkan masalah yaitu kerusakan sumber daya hayati laut, pencemaran, over eksploitasi dan konflik antara nelayan. Dalam pengelolaan sumber daya alam, kegiatan penangkapan ikan merupakan kegiatan eksploitasi.Sebagai kegiatan

8 Anjorotni, 2009, Analisis dan Evaluasi Hukum tentng Pengadilan Perikanan, Badan Pembinaan Hukum Nasional, Jakarta, hlm. 48.

9 Djoko Tribawono, 2011, Hukum Perikanan Indonesia, Citra Aditya Bakti, Jakarta, hlm. 210.

Pertanggungjawaban Pidana Terhadap Penggunaan Alat Tangkap Ikan Illegal

Oleh : Ica Karina, S.H., M.H 
eksploitatif, penangkapan ikan hanya bertujuan mengambil sumber dayayang tersedia di alam. Oleh sebab itu kegiatan penangkapan ikan harus memiliki beberapa pengaturan dan pembatasan agar tidak menghancurkan sumber daya yang ada. Dengan melihat kondisi seperti ini, UU Fishing dapat melemahkan pengelolaan sumber daya perikanan di perairan Indonesia dan menyebabkan beberapa sumber daya perikanan dibeberapa Wilayah Pengelolaan Perikanan (WPP) Indonesia mengalami over fishing. ${ }^{10}$ Efektivitas sistem sanksi pidana dalam Undang-Undang Nomor 45 Tahun 2009 tentang Perubahan atas Undang-Undang Nomor 31 Tahun 2004 tentang perikanan sebagai salah satu sarana untuk mewujudkan kebijakan lingkungan akan sangat banyak dipengaruhi beberapa faktor, salah satu diantaranya adalah perumusan kaidah hukumnya itu sendiri. Undang-Undang Nomor 45 Tahun 2009 tentang Perubahan atas Undang-Undang Nomor 31 Tahun 2004 tentang perikanan dapat memberikan efek jera terhadap pelakupelaku tindak pidana pelanggaran penangkapan ikan terutama pelaku yang dalam hal ini menggunakan alat bantu berupa bahan kimia yang dapat merusak ekosistem terumbu karang yang mungkin bisa diperbaiki namun memakan waktu yang cukup lama dan bisa meninggalkan cacat permanen pada terumbu karangtersebut. Demikian kita semua sadar bahwa setiap makhluk butuh waktu untuk berkembang biak. Inilah masalah utama dari pukat hela.Semua ikan (dewasa maupun kecil) terjaring oleh pukat helakarena ukuran lubang jalanya sangat kecil jika dibandingkan dengan jaring yang

10 Dina Sunyowati, 2013, Prort State Measures dalam upaya pencegahan terhadap UU Fishing di Indoneia, Remaja Rosdakarya, Bandung, hlm. 438. dipakai oleh nelayan tradisional.Pukat Helamenjadi masalah karena dampaknya pada lingkungan.Karena pukat helamenggunakan alat tangkapberat yang diletakkan di dasar laut, hal itu menyebabkan kehancuran ekosistem laut yaitu kerusakan terumbu karang yang merupakan habitat ikan dan juga merusak rumput laut.

\section{B. RUMUSAN MASALAH}

Berdasarkan uraian pada latar belakang tersebut di atas, maka Penulis merumuskan beberapa hal penting yang dianggap sebagai permasalahan yang akan menjadi titik tolak pembahasan dalam penelitian, yaitu sebagai berikut:

1. Bagaimana pengaturan hukum terhadap tindak pidana penggunaan alat tangkap ikan illegal?

2. Apa saja bentuk sanksi pidana/hukuman terhadap penggunaan alat tangkap ikan?

\section{KERANGKA TEORI}

Fungsi Indonesia adalah negara kepulauan dengan sebagian besar wilayahnya merupakan perairan dengan berbagai macam sumber daya alam yang berlimpah antara lain mutiara, minyak, tambang dan berbagai macam jenis ikan. Keberadaan Undang-Undang No 31 Tahun 2004 yang diubah dengan Undang-Undang No 45 Tahun 2009 dalam pasal 84 sampai dengan pasal 104 mengatur tentang ketentuan pidana. Dalam pasal 84 sampai dengan pasal 104 mengatur tindak pidana penggunaan bahan yang dapat membahayakan kelestarian sumber daya ikan, penggunaan alat penangkapan ikan, kerusakan atau pencemaran sumber daya ikan lingkungannya, tindak pidana yang berhubungan dengan pembudidayaan, dan tindak pidana lainnya. Dengan dibuatnya undangundang perikanan ini diharapkan dapat 
mencegah terjadinya penangkapan ikan secara ilegal. Namun kenyataannya masih terdapat pelanggaran di sektor perikanan.

Pada era serba terbuka ini penyuluh perikanan sebagai agen perubahan harus paham betul tentang kegiatan-kegiatan pelaku utama yang menimbulkan dampak terhadap kerusakan lingkungan perairan. Kegiatan penangkapan yang dilakukan nelayan seperti menggunakan bahan peledak, bahan beracun dan menggunakan alat tangkap trawl, bertentangan dengan kode etik penangkapan. Kegiatan ini umumnya bersifat merugikan bagi sumberdaya perairan yang ada. Kegiatan ini sematamata hanya akan memberikan dampak yang kurang baik bagi ekosistem perairan, akan tetapi memberikan keuntungan yang besar bagi nelayan. Dalam kegiatan penangkapan yang dilakukan nelayan dengan cara dan alat tangkap yang bersifat merusak yang dilakukan khususnya oleh nelayan tradisional. Untuk menangkap sebanyak-banyaknya ikan karang yang banyak, digolongkan kedalam kegiatan illegal fishing. Karena kegiatan penangkapan yang dilakukan sematamata memberikan keuntungan hanya untuk nelayan tersebut, dan berdampak kerusakan untuk ekosistem karang.Kegiatan yang umumnya dilakukan nelayan dalam melakukan penangkapan dan termasuk kedalam kegiatan illegal fishing adalah penggunaan alat tangkap yang dapat merusak ekosistem seperti kegiatan penangkapan dengan pemboman, penangkapan dengan menggunakan racun serta penggunaan alat tangkap trawl pada daerah yang memiliki karang.

Kegiatan yang marak dilakukan oleh nelayan adalah dengan menggunakan obat bius atau bahan beracun lainnya.Bahan beracun yang umum dipergunakan dalam penangkapan ikan dengan pembiusan seperti sodium ataupotassium sianida. ${ }^{11}$ Seiring dengan meningkatnya permintaan konsumen terhadap ikan hias dan hidup, memicu nelayan untuk melakukan kegiatan penangkapan yang merusak dengan menggunakan racun sianida.Kegiatan ini umum dilakukan oleh nelayan untuk memperoleh ikan hidup.

Hasil yang diperoleh dengan cara ini memang merupakan ikan yang masih hidup, tetapi penggunaannya pada daerah karang memberikan dampak yang sangat besar bagi terumbu karang. Selain itu penangkapan dengan cara ini dapat menyebabkan kepunahan jenis-jenis ikan karang tertentu. Racun tersebut dapat menyebabkan ikan besar dan kecil menjadi mabuk dan mati.Disamping mematikan ikan-ikan yang ada, sisa racun dapat menimbulkan dampak negatif bagi kehidupan terumbu karang, yang ditandai dengan perubahan warna karang yang berwarna warni menjadi putih yang lama kelamaan karang menjadi mati. Kegiatan lain yang termasuk kedalam kegiatan illegal fishing adalah penggunaan alat tangkap trawl pada daerah karang. Kegiatan ini merupakan kegiatan penangkapan yang bersifat merusak dan tidak ramah lingkungan.

\section{PEMBAHASAN}

\section{Pengaturan Hukum Tentang Tindak Pidana Perikanan}

Dalam Undang-Undang No. 31 Tahun 2004 Tentang Perikanan ini dimuat ketentuan pidana dalam Bab XV dari Pasal 84 sampai dengan Pasal 105.

\footnotetext{
11 https://suksesmina.wordpress.com/ 2015/02/16/penangkapan-ikan-yangmerusak-ekosistem-laut/ diakses pada tanggal 03 Februari 2021, pada pukul 10.00 WIB.
} 
Pasal 85 menyebutkan : 'Setiap orang yang dengan sengaja memiliki, menguasai, membawa, dan/atau menggunakan alat penangkap ikan dan/atau alat bantu penangkapan ikan yang mengganggu dan merusak keberlanjutan sumber daya ikan di kapal penangkap ikan di wilayah pengelolaan perikanan Negara Republik Indonesia sebagaimana dimaksud dalam Pasal 9 dipidana dengan pidana penjara paling lama 5 (lima) tahun dan denda paling banyak Rp. 2.000.000.000,00 (dua miliar rupiah)". Pasal 92 menyebutkan : "Setiap orang yang dengan sengaja di wilayah pengelolaan perikanan Republik Indonesia melakukan usaha perikanan di bidang penangkapan, pembudidayaan, pengangkutan, pengolahan, dan pemasaran ikan, yang tidak memiliki SIUP sebagaimana dimaksud dalam Pasal 26 ayat (1) dipidana dengan pidana penjara paling lama 8 (delapan) tahun dan denda paling banyak Rp. 1.500.000.000,00 (satu miliar lima ratus juta rupiah)".

Pasal 93 menyebutkan ayat (1) Setiap orang yang memiliki dan/atau mengoperasikan kapal penangkap ikan berbendera Indonesia melakukan penangkapan ikan di wilayah pengelolaan perikanan Negara Republik Indonesia dan/atau di laut lepas yang tidak memiliki SIPI sebagaimana dimaksud dalam Pasal 27 ayat (1) dipidana dengan pidana penjara paling lama 6 (enam) tahun dan denda paling banyak Rp. 2.000.000.000,00 (dua miliar rupiah).

Pasal 93 menyebutkan ayat (2) Setiap orang yang memiliki dan/atau mengoperasikan kapal penangkap ikan berbendera asing melakukan penangkapan ikan di wilayah pengelolaan perikanan Republik Indonesia, yang tidak memiliki SIPI sebagaimana dimaksud dalam Pasal 27 ayat (2) , dipidana dengan pidana penjara paling lama 6 (enam) tahun dan denda paling banyak Rp. 20.000.000.000,00 (dua puluh miliar rupiah).

Pasal 93 menyebutkan ayat (3) Setiap orang yang mengoperasikan kapal penangkap ikan berbendera Indonesia di wilayah pengelolaan perikanan Negara Republik Indonesia, yang tidak membawa SIPI asli sebagaimana dimaksud dalam Pasal 27 ayat (3) dipidana dengan pidana penjara paling lama 6 (enam) tahun dan denda paling banyak Rp. 2.000.000.000,00 (dua miliar rupiah). (4) Setiap orang yang mengoperasikan kapal penangkap ikan berbendera asing di ZEEI, yang tidak membawa SIPI asli sebagaimana dimaksud Pasal 27 ayat (3), dipidana dengan pidana penjara paling lama 6 (enam) tahun dan denda paling banyak Rp. 20,000.000.000,00 (dua puluh miliar rupiah).

Secara singkat dapatlah dikatakan, bahwa tindak pidana di bidang perikanan merupakan suatu perbuatan di bidang perikanan yang memuat perintah-perintah dan laranganlarangan, yang bilamana perintahperintah dan larangan-larangan tersebut dilanggar (tidak ditaati) maka pelakunya (individu atau korporasi) diancam dengan suatu pidana (stelsel pidana kumulatif) Didalam ketentuanketentuan pidana tersebut hendak dikemukakan adalah hal-hal yang relevan dengan pokok kajian, antara lain:

1. Pasal 84 ayat (1) dan (2) yang menyatakan : (1) Setiap orang yang dengan sengaja di wilayah pengelolaan perikanan Republik Indonesia melakukan penangkapan ikan dan/atau pembudidayaan ikan dengan menggunakan bahan kimia, bahan biologis, bahan peledak, alat dan/atau cara, dan/atau bangunan yang dapat merugikan dan/atau 
membahayakan kelestarian sumber daya ikan dan/atau lingkungannya sebagaimana dimaksud dalam Pasal 8 ayat (1), dipidana dengan pidana penjara paling lama 6 (enam) tahun dan denda paling banyak $\mathrm{Rp}$. 1.200.000.000,00 (satu miliar dua ratus juta rupiah) unsur-unsurnya :

a. Setiap orang (individu atau korporasi),

b. Sengaja, dolus,

c. Melakukan penangkapan ikan dan/atau pembudidayaan ikan,

d. Di wilayah pengelolaan dan/atau pembudidayaan ikan,

e. Menggunakan bahan kimia, biologis, bahan peledak, alat dan/atau cara dan/atau bangunan,

f. Merugikan dan/atau membahayakan,

g. Kelestarian sumber daya ikan dan/atau lingkungannya

h. Diancam dengan pidana; Apabila unsur-unsur tersebut terpenuhi, pelakunya (setiap orang) dikualitiser sebagai pelaku tindak pidana perikanan (illegal fishing).

Ayat (2) Nakhoda atau pemimpin kapal perikanan, ahli penangkapan ikan, dan anak buah kapal yang dengan sengaja di wilayah pengelolaan perikanan Republik Indonesia melakukan penangkapan ikan dengan menggunakan bahan kimia, bahan biologis, bahan peledak, dan/atau bangunan yang dapat merugikan dan/atau membahayakan kelestarian sumber daya ikan dan/atau lingkungannya sebagaimana dimaksud dalam Pasal 8 ayat (2), dipidana dengan pidana penjara paling lama 10 (sepuluh) tahun dan denda paling banyak Rp. 1.200.000.000,00 (satu miliar dua ratus juta rupiah)
Unsur-unsurnya :

a. Nakhoda, pemimpin kapal perikanan, ahli penangkapan ikan, anak buah kapal,

b. Sengaja

c. Dalam wilayah pengelolaan perikanan Republik Indonesia,

d. Melakukan penangkapan ikan,

e. Menggunakan bahan kimia, bahan biologis, bahan peledak, bangunan,

f. Dapat merugikan, membahayakan kelestarian sumber daya ikan, lingkungannya

g. Ancaman pidana.

Pasal 85 menyebutkan:

"Setiap orang yang dengan sengaja memiliki, menguasai, membawa, dan/atau menggunakan alat penangkap ikan dan/atau alat bantu penangkapan ikan yang mengganggu dan merusak keberlanjutan sumber daya ikan di kapal penangkap ikan di wilayah pengelolaan perikanan Negara Republik Indonesia sebagaimana dimaksud dalam Pasal 9 dipidana dengan pidana penjara paling lama 5 (lima) tahun dan denda paling banyak Rp. 2.000.000.000,00 (dua miliar rupiah).

\section{Unsur-unsurnya :}

a. Setiap orang (manusia, korporasi),

b. Dengan sengaja (dolus),

c. Memiliki, menguasai, membawa, dan atau menggunakan alat penangkap ikan, atau alat bantu penangkap ikan,

d. Mengganggu, merusak, 
e. Keberlanjutan sumber daya ikan,

f. Kapal penangkap ikan,

g. Di wilayah pengelolaan perikanan negara Republik Indonesia,

h. Ancaman pidana.

Pasal 92 menyebutkan :

"Setiap orang yang dengan sengaja di wilayah pengelolaan perikanan Republik Indonesia melakukan usaha perikanan di bidang penangkapan, pembudidayaan, pengangkutan, pengolahan dan pemasaran ikan, yang tidak memiliki SIUP sebagaimana dimaksud dalam Pasal 26 ayat (1) dipidana dengan pidana penjara paling lama 8 (delapan) tahun dan denda paling banyak Rp. 1.500.000.000,- (satu miliar lima ratus juta rupiah)".

Unsur-unsurnya :

a. Setiap orang,

b. Dengan sengaja,

c. Dalam wilayah perikanan negara Republik Indonesia,

d. Melakukan usaha perikanan,

e. Di bidang penangkapan, pembudidayaan, pengangkutan, pengolahan, dan pemasaran ikan,

f. Tidak memiliki SIUP (Surat Izin Usaha Perikanan),

g. Ancaman pidana;

Terpenuhinya semua unsur-unsur dalam Pasal 85, Pasal 92, Pasal 93, Pasal 94A, maka pelakunya telah melakukan tindak pidana perikanan (illegal fishing). Ada baiknya dikemukakan pula Pasal 69 yang menyebutkan : (1) Kapal Pengawas perikanan berfungsi melaksanakan pengawasan dan penegakan hukum di bidang perikanan dalam wilayah pengelolaan perikanan Negara Republik Indonesia; (2) Kapal pengawas perikanan sebagaimana dimaksud pada ayat (1), dapat dilengkapi dengan senjata api; (3) Kapal pengawas perikanan dapat menghentikan, memeriksa, membawa dan menahan kapal yang diduga atau patut diduga melakukan pelanggaran di wilayah pengelolaan perikanan Negara Republik Indonesia ke pelabuhan terdekat untuk pemprosesan lebih lanjut; (4) Dalam melaksanakan fungsi sebagaimana dimaksud pada ayat (1) penyidik dan/atau pengawas perikanan dapat melakukan tindakan khusus berupa pembakaran dan/atau penenggelaman kapal perikanan yang berbendera asing berdasarkan bukti permulaan yang cukup; Sehubungan dengan Pasal 69 ayat (4) ini, maka Menteri Kelautan dan Perikanan (ibu Susi Pudjiastuti) telah melakukan penenggelaman kapal ikan dengan menggunakan dinamit dengan daya ledak rendah. Adanya ancaman pidana kumulatif dalam undang-undang di bidang perikanan (Undang-Undang No. 45 Tahun 2009 Tentang Perubahan Atas Undang-Undang No. 31 Tahun 2004 ) tidaklah berarti dengan serta merta illegal fishing dapat dicegah dan dibasmi sampai tuntas ke akar-akarnya.

\section{Bentuk Sanksi pidana/Hukuman} Terhadap Penggunaan Alat Tangkap Ikan Illegal

Penggunaan sanksi hukum pidana dalam mengatur dan mengendalikan masyarakat melalui perundangundangan pada dasarnya merupakan bagian dari suatu langkah kebijakan. Namun menurut Barda Nawawi Arief mengingat keterbatasan-keterbatasan dan kelemahan-kelemahan hukum pidana adalah $:^{12}$

12 Barda Nawawi Arief, 2005, Bunga Rampai Kebijakan Hukum Pidana, PT. Citra Aditya Bakti Bandung, hlm 42. 
1. Sebab-sebab kesalahan yang komplek berada diluar jangkauan hukum pidana

2. Hukum pidana hanya merupakan bagian kecil (sub sistem) dari sarana kontrol sosial yang tidak mungkin mengatasi masalah kejahatan sebagai masalah kemanusiaan dan kemasyarakatan yang sangat komplek

3. Penggunaan hukum pidana dalam mengatasi kejahatan hanya merupakan pengobatan simptomatik dan bukan pengobatan kausatif

4. Sistem pemidanaan bersifat fragmentaris dan individual person dan bukan struktural atau fungsional

5. Berfungsinya atau bekerjanya hukum pidana memerlukan sarana pendukung yang lebih bervariasi dan menuntut biaya tinggi;

Untuk itu pula penanganan kasus illegal fishing harus dilakukan tidak hanya dengan upaya penal juga harus pula disandingkan dengan upaya non penal. Berhubung dengan hal tersebut menurut G.P. Hoefnagel dalam bukunya Barda Nawawi Arief, ${ }^{13}$ maka upaya penanggulangan kejahatan dengan penal dan non penal dapat ditempuh dengan jalan;

a. Penerapan hukum pidana (Criminal Law Application);

b. Pencegahan tanpa pidana (Prevention without punishment);

c. Mempengaruhi pandangan masyarakat mengenai kejahatan dan pemidanaan melalui media massa; Secara garis besarnya ada 2 (dua) penanggulangan kejahatan

1) Jalur penal (hukum pidana) Lebih menitikberatkan pada sifat represif (penumpasan, pemberantasan, penindasan) sesudah kejahatan terjadi.

2) Jalur non penal (diluar hukum pidana) Lebih menitikberatkan pada sifat preventif (pencegahan, penangkalan, pengendalian) sebelum kejahatan terjadi. Namun harus pula diingat dalam tindakan represif pada dasarnya dapat juga dilihat sebagai tindakan preventif dalam arti luas. Jalur non penal adalah Pencegahan tanpa pidana, mempengaruhi pandangan masyarakat mengenai kejahatan dan pemidanaan lewat media massa. Upaya penanggulangan lewat jalur non penal, lebih bersifat tindakan pencegahan, agar tidak terjadi kejahatan maka sasaran utamanya adalah menangani faktor-faktor kondusif tersebut antara lain berpusat pada masalahmasalah, kondisi sosial (social policy) yang langsung atau tidak langsung dapat menyuburkan, menimbulkan kejahatan. Jadi dilihat dari politik criminal dalam arti luas maka upaya non penal menduduki posisi kunci dan strategis dari upaya politik criminal.Posisi kunci dan strategis dalam menanggulangi sebab-sebab timbulnya kejahatan.

Pada kongres PBB tahun 1980 di Ciracas dalam pertimbanganpertimbangan resolusinya antara lain disebutkan: ${ }^{14}$

a. Masalah kejahatan merintangi kemajuan untuk mencapai

${ }^{13}$ Ibid, hlm. 46-47

${ }^{14}$ Ibid., hlm 43

Pertanggungjawaban Pidana Terhadap Penggunaan Alat Tangkap Ikan Illegal

Oleh : Ica Karina, S.H., M.H 
kualitas lingkungan hidup yang layak bagi semua orang.

b. Strategi pencegahan kejahatan harus didasarkan pada penghapusan sebab-sebab dan kondisi-kondisi yang menimbulkan kejahatan.

c. Penyebab utama dari kejahatan di negara berkembang adalah ketimpangan sosial, diskriminasi ras, dan diskriminasi nasional, standar hidup yang rendah, pengangguran, buta huruf diantara golongan besar penduduk.

Kegiatan illegal fishing yang sering terjadi di Indonesia adalah :

1. Penangkapan ikan tanpa izin

2. Penangkapan ikan dengan menggunakan izin palsu.

3. Penangkapan ikan dengan menggunakan alat tangkap terlarang

4. Penangkapan ikan dengan jenis (species) yang tidak sesuai dengan izin / yang merupakan yang dilindungi.

Penyebab terjadinya illegal fishing adalah meningkat dan tingginya permintaan ikan (DL/LN), lemahnya armada perikanan nasional, izin/ dokumen pendukung dikeluarkan lebih dari satu instansi, lemahnya pengawasan dan penegakan hukum di laut, lemahnya delik tuntutan dan putusan pengadilan, belum adanya visi yang sama antar aparatur penegak hukum dan lemahnya peraturan perundang-undangan dan ketentuan pidana. Pukat hela atau lebih tepatnya Pukat Udang, karena memang penggunaan awalnya untuk menangkap udang di perairan dasar laut.Pukat Hela adalah jaring yang berbentuk kantong yang ditarik oleh satu atau dua kapal pukat, bisa melalui samping atau
belakang.Sebuah alat yang efektif tapi sayangnya tidak selektif, karena alat ini merusak semua yang dilewatinya.

\section{E. KESIMPULAN}

1. Upaya Represif yaitu dengan cara menangkap, menahan dan memeriksa tersangka, menggeledah sarana dan prasarana perikanan yang digunakan dalam atau menjadi tempat melakukan tindak pidana di bidang perikanan berupa memeriksa kelengkapan dan keabsahan dokumen usaha perikanan, dan menandatangani berita acara dan menyerahkan berkas acara ke kejaksaan. Pengaturan penggunaan alat tangkap perikanan menurut Undang-Undang Nomor 45 Tahun 2009 Tentang Perubahan Undang-Undang Nomor 31 Tahun 2004 tentang Perikanan tidak secara jelas terdapat pengaturan tentang penggunaan alat tangkap perikanan di Indonesia. Secara sederhana hanya terdapat Pasal 7 UndangUndang Nomor 45 Tahun 2009 Tentang Perikanan yang mengatur tentang kekuasaan Menteri Kelautan untuk menetapkan aturan tentang Jenis, jumlah ukuran, dan alat tangkap ikan yang diizinkan beroperasi di Indonesia. Berdasarkan kewenangan tersebut Menteri Kelautan telah menetapkan Permen KP Nomor. 06/MEN/2010 Tentang Alat Penangkapan Ikan di Wilayah Pengelolaan Perikanan.

2. Hukum terhadap pelaku tindak pidana di bidang perikanan pada prinsipnya hanya dapat dilakukan apabila diketahui 
terdapat cukup bukti telah terjadi tindak pidana di wilayah Zona Ekonomi Eksklusif Indonesia sebagaimana diatur dalam Undang-Undang Nomor 45 Tahun 2009 tentang Perikanan yang dilakukan oleh setiap orang atau badan hukum, selanjutnya terhadap pelaku tindak pidana tersebut dilakukan pemeriksaan berupa penyidikan. Sanksi pidana menurut undang-undang perikanan bisa berupa sanksi administrasi (pencabutan ijin), kurungan badan (penjara) atau pun denda. dan dengan sanksi tersebur dapat menimbulkan efek jera bagi pelaku illegal fishing di Zona Ekonomi Eksklusif Indonesia. Khusus dibidang perikanan yang ada didalam undang-undang ZEEI secara eksklusif sudah diatur didalam UndangUndang Perikanan yang baru yaitu UU RI No. 34 tahun 2009 tentang perubahan UU RI No. 31 Tahun 2004 tentang Perikanan.

\section{SARAN}

1. Kepada aparat penegak hukum agar dilakukan upaya peningkatan sumber daya manusia, peningkatan sarana dan prasarana operasional penunjang, dan peningkatan operasi pengamanan secara rutin, terpadu, dan terkoordinasi.Agar Hakim dalam menjatuhkan hukuman agar dapat memerhatikan nasib para nelayan dimana para nelayan tidak memiliki pendidikan tinggi dan ilmu pengetahuan terlebih pengetahuan hukum perikanan dan agar dapat dibina serta diberikan pengetahuan tentang illegal fishing agar tidak terulang kembali.

2. Terhadap sanksi pidana Ilegall Fishing agar diperkuat dan lebih mengikat sehingga para masyarakat lebih takut untuk melakukan perbuatan melanggar hukum terlebih melanggar Undang-Undang tentang Perikanan serta dibuat UndangUndang terbaru yang lebih baik lagi.Perlu menyamakan persepsi antar setiap stakeholder dan masyarakat untuk menentukan sikap bagaimana sebaiknya pengaturan penggunaan alat tangkap Trawls diberlakukan di Indonesia dan diharapkan kepada pemerintah untuk dapat merealisasikan kebijakan yang telah dibuat secara konsisten dan bertanggungjawab dengan berbagai stakeholder di bidang perikanan di Indonesia. Untuk mendapatkan kejelasan terkait pengaturan alat tangkap Trawls di Indonesia maka diharapkan kepada pemerintah agar melakukan sinkronisasi materi muatan peraturan perundangundangan di bidang Perikanan secara tepat dan terpadu sehingga tidak terjadi pertentangan antara aturan yang satu dengan yang lainnya dalam mengatur hal yang sama

\section{DAFTAR PUSTAKA}

Anjorotni, 2009, Analisis dan Evaluasi
Hukum tentng Pengadilan
Perikanan, Badan Pembinaan
Hukum Nasional, Jakarta.
Barda
Nawawi Arief, 2005, Bunga
Rampai Kebijakan Hukum


Pidana, PT. Citra Aditya Bakti Bandung.

Chairul Anwar, 1998, Horizon Baru Hukum Laut Internasional, Rhineka Cipta, Jakarta.

Dina Sunyowati, 2013, Prort State Measures dalam upaya pencegahan terhadap UU Fishing di Indoneia, Remaja Rosdakarya, Bandung.

Djoko Tribawono, 2011, Hukum Perikanan Indonesia, Citra Aditya Bakti, Jakarta, hlm. 210.

E Mantjoro dan Potoh O, 1993, Internasional Fishier Policy (Kebijaksanaan Perikanan Internasional), Alumni, Bandung.

Eddy Afrianto, 1996, Kamus Istilah Perikanan, Kanisius, Bandung.

Frans E. Likadja, 1998, Bungan Rumpai Hukum Laut Internasional, Bina Cipta, Bandung.

https://suksesmina.wordpress.com/2015 /02/16/penangkapan-ikan-yangmerusak-ekosistem-laut/ diakses pada tanggal 03 Februari 2021, pada pukul $10.00 \mathrm{WIB}$.

Supriadi dan Alimudin, 2001, Hukum Perikanan Di Indonesia, Sinar Grafika, Jakarta. 